\title{
冠動脈疾患や不整脈を合併した大動脈弁病変に 対する複合開心術の検討
}

\begin{tabular}{|c|c|c|c|c|c|c|c|}
\hline & 博 史 & 畑 & & 隆 登 & 津 & & \\
\hline 4 & 明 & 濱 & 中 & 荘 & 吉 & & 䳡 \\
\hline & 恒太郎 & 黒 & 木 & 慶一郎 & & & \\
\hline
\end{tabular}

\begin{abstract}
近年, 大動脈弁病変と合併する他の心疾患に対する複合開心術が増加傾向にある. 1990 年 1 月から 1996 年 11 月までに当科で施行した ( 1 ) AVR+CABG 同時施行例 25 例（男：女 $=19 ： 6$, 年齢54〜 77 歳, 平均年齢 $67.1 \pm 7.2$ 歳）と，（2）AVR+TAP+Maze 同時施行例 2 例について検討を加えた。 (1) AVR+CABG 25 例の病院内死亡はなかった。AVR は全例 SJM 弁を使用した。 CABG では平 均グラフト本数は 1.41 /症例で, 積極的に動脈グラフトを 31 本中 20 本 $(64.5 \%)$ に使用し, 術後早 期開存率は 100\%であった。（2）AVR+TAP+Maze 症例ではTAP は DeVega 法を用いて行い, Maze 手術は cryoablation を併用した modified Maze 手術を行い 2 例とも術後は洞調律が得られ た. 大動脈弁手術と同時に冠動脈疾患や不整脈に対する手術を積極的に併用することにより良好な手 術成績が得られると考えられた. 日心外会誌 27 巻 4 号 : 201-206 (1998)

Keywords：複合開心術, 大動脈弁置換術, 冠動脈バイパス手術, modified Maze 手術, 動脈グ ラフト
\end{abstract}

\begin{abstract}
Surgery for Aortic Valve Disease Combined with Coronary Artery Disease and Arrhythmia Hiroshi Furukawa, Takato Hata, Yoshimasa Tsushima, Mitsuaki Matsumoto, Souhei Hamanaka, Hidenori Yoshitaka, Koutarou Fujiwara, Keiichirou Kuroki and Zenichi Masuda (Department of Cardiovascular Surgery, Cardiac Center of Sakakibara Hospital, Okayama, Japan)

Aortic valve disease is frequently associated with coronary artery disease and arrythmia. Recently, the mortality of aortic valve replacement has decreased because of more effective myocardial protection, so operations that combine aortic valve replacement and coronary bypass grafting or the Maze procedure for atrial fibrillation have been performed. We treated 25 patients undergoing aortic valve replacement combined with coronary bypass grafting and 2 patients undergoing aortic valve replacement with a modified Maze procedure from 1990 to 1996. Among the patients undergoing aortic valve replacement combined with coronary bypass grafting, there were no perioperative deaths and no development of coronary artery disease, malfunction of mechanical valve, or thrombosis. Two patients undergoing aortic valve replacement with a modified Maze procedure and tricuspid valve annuloplasty have reverted to sinus rhythm from atrial fibrillation with no anti-arrythmic agent. Surgery for combined aortic valve disease and coronary artery disease or arrythmia resulted in an improvement of late survival and quality of life. Jpn. J. Cardiovasc. Surg. 27: 201-206 (1998)
\end{abstract}

大動脈弁単独手術の成績向上とともに冠動脈疾 患や不整脈を合併した複合開心術が増加傾向にあ る. 今回我々は, 大動脈弁病変と合併する他の心 疾患に対し複合開心術を行い, その術式および成 績, 有用性について検討し若干の文献的考察を加

1997 年 11 月 12 日受付， 1998 年 2 月 12 日採用

心臟病センター榊原病院心臟血管外科 $\bar{\top} 700-0823$ 岡山市丸 の内 2-1-10

本論文の要旨は第 27 回日本心臟血管外科学会総会 (1997 年 2 月，尼ケ崎）にて発表した.
えたので報告する。

\section{対象と方法}

1990 年 1 月から 1996 年 11 月までに当科で施 行した大動脈弁置換術と冠動脈バイパス手術の同 時手術（以下 AVR +CABG）25 例と大動脈弁置 換術と三尖弁形成術, Maze 手術の同時手術（以 下AVR+TAP+Maze）2 例を対象とした。 
表 1 AVR +CABG 症例(1990～1996)

\begin{tabular}{lcc}
\hline & & 平均 \\
\hline 症例数 & 25 例 & - \\
年 齢 & $54 \sim 77$ 歳 & $67.1 \pm 7.2$ 歳 \\
性 & 男 $:$ 女 $=19: 6$ & - \\
術前心機能 & $\mathrm{LVEF}=31 \sim 84 \%$ & $65.5 \pm 14.1 \%$ \\
手術時間 & 4 時間 30 分 $\sim 8$ 時間 & 6 時間 26 分 \\
体外循環時間 & $109 \sim 205$ 分 & $154.8 \pm 24.8$ 分 \\
大動脈遮断時間 & $78 \sim 150$ 分 & $118.0 \pm 21.9$ 分 \\
\hline
\end{tabular}

\section{AVR+CABG 症例（表 1）}

症例数は 25 例, 年歯 は 54 77 歳, 平均 $67.1 \pm 7.2$ 歳, 男女比は 19:6であった。この 25 例は同期間の AVR 症例の $11.3 \%, \mathrm{CABG}$ 症例 の $4.9 \%$ であった。大動脈弁病変は, 逆流が全く なく圧較差が $50 \mathrm{mmHg}$ 以上の狭窄症が 2 例 (AS)，逆流を $\mathrm{I}^{\circ}$ 認め圧較差が $50 \mathrm{mmHg}$ 以上の 狭窄症が 3 例 (ASr), 逆流が $\mathrm{II}^{\circ}$ から $\mathrm{III}^{\circ}$ で圧較 差が $50 \mathrm{mmHg}$ 以上の狭窄症が 9 例 (ASR), 逆 流が III 以上で圧較差が $50 \mathrm{mmHg}$ 以下の狭窄症 が 2 例 (AsR)，圧較差がなく逆流が $\mathrm{III}^{\circ}$ 以上の 閉鎖不全症が 9 例（AR）であった（図 1 左）。 25 例中压較差 $100 \mathrm{mmHg}$ 以上の高度の大動脈弁 狭窄症を 5 例に認めた。冠動脈病変は左冠動脈主 幹部病変 (LMT 病変) と右冠動脈病変を含む 3 枝病変 $(T V D)$ が 6 例, LMT 単独病変を含む 2 枝病変（DVD）が 11 例， 1 枝病変が 8 例であっ た(図 1 右)。2 5 例中 LMT 病変を 4 例に認め た。また 1 枝病変 8 例のうち 5 例が左冠動脈前下 行枝病変 ( $\mathrm{LAD}$ 病変) であった。術前の心機能 は心臓カテーテル検査による左室造影を行い得た 25 例中 23 例で左室駆出率 (LVEF) が 31 $84 \%$, 平均 $65.5 \pm 14.1 \%$ あった。術前の 心臓超音波検査による左室拡張末期径（LVDd） は，行い得た 25 例中 23 例で平均 $49.3 \pm 8.5 \mathrm{~mm}$ であった。手術は全例完全体外循環，大動脈遮断 下に行い, 体外循環時間は109２05分，平均 $154.8 \pm 24.8$ 分, 大動脈遮断時間は $78 \sim 150$ 分, 平均 $118.0 \pm 21.9$ 分であった。手術時間は 4 時間 30 分から 8 時間, 平均 6 時間 26 分であった。術 中 25 例中 4 例 $(16 \%)$ に大動脈弁二尖弁を認め た。大動脈弁置換術には全例 SJM 弁を使用し,

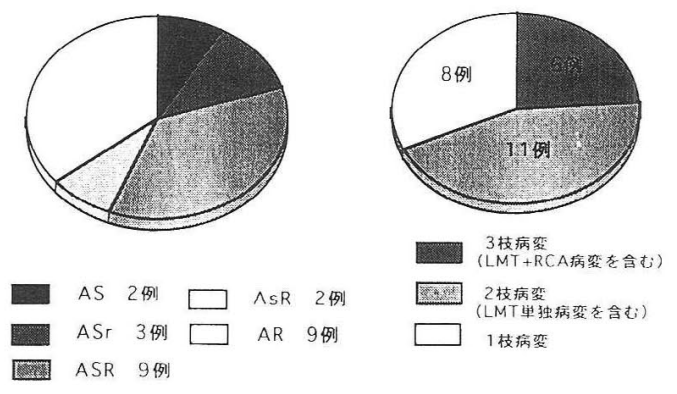

図1 AVR $+\mathrm{CABG}$ 症例の術前診断 左: 大動脈弁病変, 右 : 冠動脈病変。

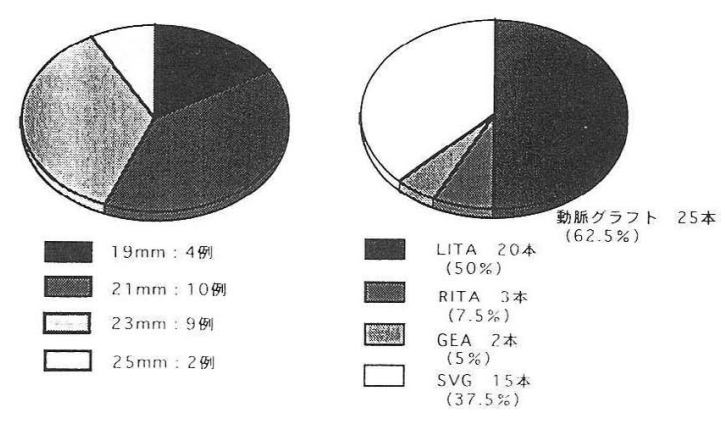

図 $2 A V R+C A B G$ 症例の手術内容 左：人工弁サイズ, 右：グラフト。

使用した人工弁のサイズは $19 \mathrm{~mm}$ が 4 例, 21 $\mathrm{mm}$ が 10 例, $23 \mathrm{~mm}$ が 9 例, $25 \mathrm{~mm}$ が 2 例で あった (図 2 左)。冠動脈バイパス手術に使用し たグラフトは計 40 本で, 動脈グラフトが 25 本 $(62.5 \%)$, 静脈グラフトが 15 本 $(37.5 \%)$ であ った。動脈グラフトは左内胸動脈が 20 本, 右内 胸動脈が 3 本, 右胃大網動脈が 2 本であった（図 2右)。心筋保護は全例に心筋保護液として GIK を使用し, 初回 $20 \mathrm{ml} / \mathrm{kg}$ を上行大動脈から順行 
表 2 AVR + TAP + Maze 症例

\begin{tabular}{lcc}
\hline & 症例 1 & 症例 2 \\
\hline 年 齢 & 70 & 75 \\
性 & 男性 & 女性 \\
術前診断 & ASR, TR, af & ASr, TR, af \\
術前胸部 X-P 上 CTR & $56 \%$ & $70 \%$ \\
心房細動歴 & 8 年 & 3 年 \\
心工コ一上左房径 (LAD) & $41 \mathrm{~mm}$ & $63 \mathrm{~mm}$ \\
術前心機能(LVEF) & $72 \%$ & $73 \%$ \\
手術時間 & 4 時間 15 分 & 4 時間 15 分 \\
体外循環時間 & 132 分 & 152 分 \\
大動脈遮断時間 & 100 分 & 121 分 \\
\hline
\end{tabular}

性にあるいは冠動脈洞から逆行性に注入し，以後 は30 分毎に間欠的に逆行性冠灌流を併用しなが ら順行性あるいは冠動脈に選択的に $10 \mathrm{ml} / \mathrm{kg}$ 注 入し, 最後に warm blood GIKを注入する方法 で行った. 手術は体外循環開始, 大動脈遮断後に まず冠動脈バイパス手術の末梢側を吻合し，大動 脈弁置換術を行った。心筋保護の方法は大動脈弁 狭窄症優位の場合は初回の心筋保護を順行性ある いは逆行性に注入するが，大動脈弁閉鎖不全症が III 以上ある場合, あるいは心筋保護を順行性に 注入しても上行大動脈壁に十分な圧がかからず心 筋保護が不十分であると考えられた場合は，初回 の心筋保護を大動脈遮断後すぐに大動脈を切開 し，逆行性冠灌流を併用しながら選択的に冠動脈 に注入するようにした。

\section{AVR+TAP+Maze 症例（表 2）}

〔症例 1〕70 歳, 男性. 術前診断は大動脈弁狭 窄兼閉鎖不全症，三尖弁閉鎖不全症，発作性心房 細動であった。術前の胸部 X 線上 CTR 56\%, 肺榃血所見等は認めなかった。術前は心電図上心 房細動で心房細動歴は 8 年であった。心蔵超音波 検査上圧較差 $80 \mathrm{mmHg}$, 心臓カテーテル検査に よる引き抜きで圧較差 $70 \mathrm{mmHg}$ の大動脈弁狭窄 症を認め, 大動脈弁閉鎖不全症は大動脈造影上 III であった。術前の心機能は心臓力テーテルの 左室造影による LVEF で $71 \%$ と良好であった。 左房径（LAD） は心臟超音波検査上 $4.1 \mathrm{~cm}$ であ った。手術は完全体外循環，大動脈遮断下にまず 大動脈切開し初回心筋保護を冠動脈に選択的に行
い, AVR施行後DeVega 法によるTAPを行 い, Maze（III）の切開線を cryoablationにて 代用した modified Maze 手術を施行した。体外 循環時間 132 分，大動脈遮断時間 100 分，手術時 間 4 時間 15 分にて手術を終了した。

〔症例 2〕 75 歳，女性. 術前診断は大動脈弁狭 窄兼閉鎖不全症，三尖弁閉鎖不全症，発作性心房 細動であった。術前の胸部 X 線上 CTR 70\%, 軽度の肺鬱血所見を認めた。術前は心電図上心房 細動で心房細動歴は 3 年であった。心臓超音波検 査上圧較差 $121 \mathrm{mmHg}$ の大動脈弁狭窄症を認め, 大動脈弁閉鎖不全症は心臓超音波検査上軽度であ った。術前の心機能は左室駆出率 (LVEF) で $73 \%$, 左室短縮率 (LVFS) が 0.42 と良好であ った。左房径（LAD）は心臓超音波検查上 6.3 $\mathrm{cm}$ と拡大していた。手術は完全体外循環，大動 脈遮断下に順行性に初回の心筋保護を行い, AVR 施行後DeVega 法によるTAPを行い, Maze（III）の切開線を cryoablationにて代用 した modified Maze 手術を施行した。体外循環 時間 152 分，大動脈遮断時間 121 分，手術時間 4 時間 15 分にて手術を終了した。

\section{結果}

\section{AVR+CABG 症例（表 1）}

25 例中 2 例に体外循環からの離脱時に IABP を必要としたが，それ以外体外循環からの離脱困 難な症例やPCPS などの機械的補助循環を必要 とする症例はなかった。また，25例中 13 例 


\section{症例 1}
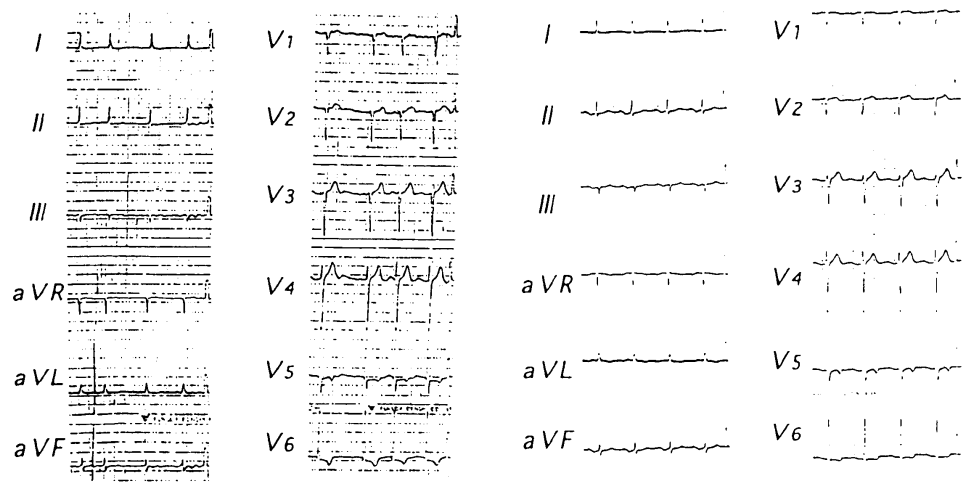

\section{症例 2}
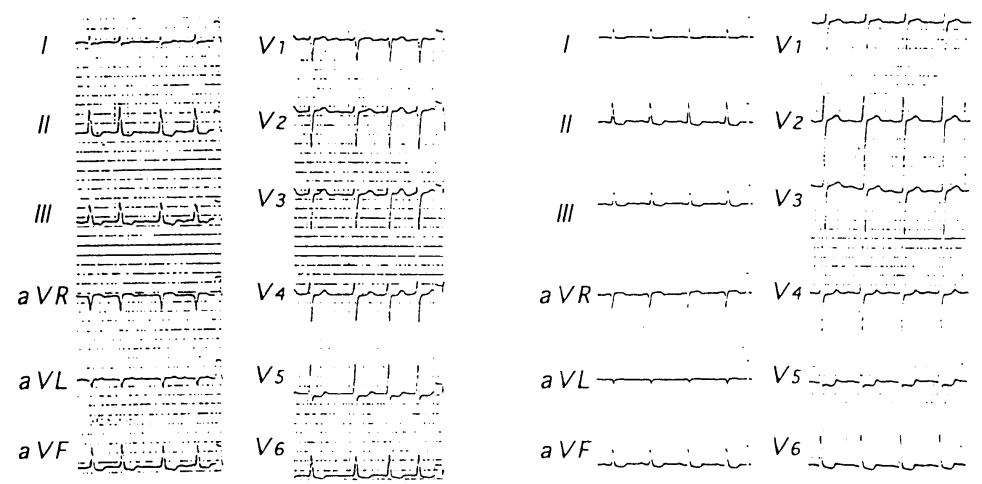

図 3 術前後の心電図

（52\%）が無輸血手術であった。術後約 3 週間後 の心臓カテーテル検査にてグラフトの開存を確認 し得た 17 症例, 24 本全てのグラフト開存を認め た。また病院内死亡はなかった。1996 年 11 月現 在, 人工弁機能不全や血栓症の発生および心筋梗 塞などの虚血性心疾患の進展や増悪はなかった。

2. AVR+TAP+Maze 症例（表 2）

症例 1 : 術後は順調に経過し, 術直後から正常 洞調律に回復し, I の AV block は認められるも のの上室性および心室性期外収縮を認めず，現在 外来にて抗不整脈薬の投与なしで正常洞調律を維 持している(図 3).

症例 2 : 術後順調に経過し術直後加正常洞調 律に回復したが, 術後 3 日目より $2: 1$ の心房粗 動になり電気的除細動によって正常洞調律に回復 し, 現在外来にて抗不整脈薬の投与なしで正常洞 調律を維持している (図 3).

\section{考察}

近年虚血性心疾患の増加につれ後天性弁膜症に 虚血性心疾患を合併することは少なくない.大動 脈弁弁膜症では約 30\%に虚血性心疾患を合併す ると報告されているが1)，診断技術の発達によ り,さらに大動脈弁弁膜症と同時に冠動脈病変が 発見される機会が増加している. 大動脈弁病変単 独手術の成績向上とともに，大動脈弁病変に合併 した冠動脈病変に対して積極的に同時手術が行わ れるようになったが，その同時手術の必要性につ いていくつか議論されている2). Bonowらや Nunley らは冠動脈バイパス手術（CABG）を同 時に行わなくても手術死亡率や遠隔期死亡率に有 意な差はないと報告している ${ }^{3,4)}$. さらに Bonow らは，冠動脈病変を合併し $\mathrm{CABG}$ を施行しなか った AVR 症例において術後 15\%の症例に冠動 
脈病変の進行を認め, 6\%の症例に CABG が必要 であったとしている。一方 Kirklin らは積極的に 合併手術を行うべきであるとしているが5)，その 理由として術後遠隔期の冠動脈閉塞による心筋梗 塞のリスクを減少させるからであるとしている. $\mathrm{AVR}$ と同時に CABG を施行する利点としては, 原らが報告するように術後冠血流が十分に得られ れば術後急性期および慢性期の心機能改善に有効 であると考えられる点があげられる ${ }^{6)}$ また CABG を併用することによって術中の冠動脈病 変領域への十分な心筋保護を早期に行うことがで きると考えられる。このような複合開心術の場 合, 手術時間の延長や体外循環時間の延長により 術中のリスクが高くなることが心配されるが7, 時間の短縮とグラフトの長期開存性の観点から, 動脈グラフトを積極的に使用すべきであると考え られる。動脈グラフトの使用は吻合箇所を少なく し体外循環時間の短縮が期待できるだけでなく, 早期冠血流の再開を図ることができる。さらに大 動脈遮断後先に冠動脈末梢側を吻合することによ り，吻合したグラフトから心筋保護液を注入する ことにより冠動脈病変領域への心筋保護を早期に 行うことができる.動脈グラフトを積極的に使用 した結果，われわれが経験した 25 例の平均体外 循環時間は 154.8 分, 大動脈遮断時間は 118.0 分 と通常の開心術として許容できる範囲であったと 考えられる. 最近冠動脈病変の重症化により LMT 病変を含む 2 枝病変以上を有する症例が増 加しているが，実際われわれが経験した 25 例中 17 例 $(68 \%)$ が LMT 病変を含む 2 枝病変以上 であった。これらの症例に対し CABG を同時に 施行せず放置した場合, 術後の虚血性心疾患の進 行のリスクはかなり増加するものと考えられ, 当 科では大動脈病変に有意な冠動脈狭窄を合併し, 病変より末梢に吻合可能な冠動脈が存在し, 十分 な支配領域を有する病変に対しては, 積極的に CABG を同時に施行する方針とした。一方 Cox らによる Maze 手術の考案と小坂井らによるそ の手術成績の向上の報告などから 8 11), 今まで放 置あるいは経過観察となって積極的に治療されて いなかった大動脈病変に合併する発作性心房細動 に対する外科的治療も行われるようになってき
た. Maze 手術は孤立性発作性心房細動に対して 行われることもあるが12), 後天性弁膜症に合併し た心房細動に対して行われる場合が多い. 僧帽弁 疾患の場合，長期間の心房負荷による心房の拡大 から心房細動を合併することが多く, Maze 手術 を同時に施行する場合が多く認められ，良好な成 績が得られている。これに対して大動脈弁疾患に 心房細動を合併する場合，手術手技上の煩雑性あ るいは心房細動歴が短いなどによる自然回復への 期待などから，それ程積極的に Maze 手術は施 行されていない.しかし, 安倍らの報告のように 僧帽弁手術だけでなく大動脈弁手術において同時 にMaze 手術を施行し良好な結果が得られてお り ${ }^{13)}$, Maze 手術の成績が安定化してきた現在で は, 大動脈弁手術と Maze 手術との同時手術は 有用であると考えられる。一方で，手術手技上大 動脈弁の手術に加え両心房に切開を加える Maze 手術の同時施行は, 体外循環時間の延長とそれに よる不十分な心筋保護などが懸念されるが，われ われはMaze（III）の切開線を cryoablationに て代用した modified Maze手術を施行してお $\eta^{14)}, \mathrm{AVR}+\mathrm{TAP}+\mathrm{Maze}$ を行った 2 例の平均 体外循環時間は 142 分, 大動脈遮断時間は 110.5 分と通常の開心術としては許容できる範囲内であ ったと考えられる。さらに modified Maze 手術 を施行することにより体外循環および手術時間の 短縮だけでなく, 術後抗不整脈薬なしで洞調律が 得られ，良好な結果が得られたと考えられた。

\section{結語}

冠動脈疾患や不整脈を合併した大動脈弁疾患に 対し, 積極的に同時手術を行い良好な結果を得 た。様久な対策により積極的な適応を考慮すべき であると考えられた。

\section{文献}

1) Graboys, T. B. and Cohn, P. F.: The prevalence of angina pectoris and abnormal coronary arteriograms in severe aortic valvular disease. Am. Heart J. 93 : 382, 1977.

2) 中井義廣, 坂東正章, 吉田 修ほか: 弁膜症と冠 動脈に対する手術. 胸部外科 39：841-849, 1986.

3) Bonow, R. O., Kent, K. M., Rosing, D. R. et al. : 
Aortic valve replacement without myocardial revascularization in patients with combined aortic valvular and coronary artery disease. Circulation 63: 243-251, 1981.

4) Nunley, D. L., Grunkemeier, G. L. and Starr, A.: Aortic valve replacement with coronary bypass grafting. J. Thorac. Cardiovasc. Surg. 85: 705-711, 1983.

5) Kirklin, J. W. and Kouchoukos, N. T.: Aortic valve replacement without myocardial revascularization. Circulation 63: 243, 1981.

6）原陽一, 上平 聡, 小林 哲ほか：冠血行再建 術を同時に施行した弁膜手術例の検討. 日心外会 誌 21 : 172-176, 1992.

7）磯村 正, 久冨光一, 平野顕夫ほか：動脈グラフ トによる冠動脈バイパス術と弁疾患の合併手術. 日心外会誌 21：122-125, 1992.

8) Cox, J. L., Schuessler, R. B., D'Agostino, H. J. et al.: The surgical treatment of atrial fibrillation III. Development of a definitive surgical procedure. J. Thorac. Cardiovasc. Surg. 101 : 569-583, 1991.
9) Cox, J. L.: The surgical treatment of atrial fibrillation IV. Surgical technique. J. Thorac. Cardiovasc. Surg. 101 : 584-592, 1991.

10) Cox, J. L., Boineau, J. P., Schuessler, R. B. et al. : Five-year experience with the maze procedure for atrial fibrillation. Ann. Thorac. Surg. 56 : 814-824, 1993.

11) Kosakai, Y., Kawaguchi, A., Isobe, F. et al. Cox maze procedure for chronic atrial fibrillation associated with miral valve disease. J. Thorac. Cardiovasc. Surg. 108: 1049-1055, 1994.

12）秋本剛秀，竹村隆広，大野英昭浮：孤立性発作 性心房細動患者のQuality of lifeの改善に対し Maze 手術が著効した 1 例. 呼吸と循環 43: 10391042, 1995.

13）安倍十三夫, 桑木賢次, 馬渡 徹ほか：弁膜症に 合併する慢性心房細動に対する Maze 手術の経 験. 胸部外科 49: 709-715, 1996.

14）小松幹志, 安倍十三夫, 桑木賢次ほか：心房細動 を合併した弁膜症に対する modified Maze 手術 の臨床治験. 心臟 28(Suppl. 3) : 7-8, 1996. 